\title{
งารสารวิศวกรSแศาสกร์
}

\section{ฮิวริสติกสำหรับการจัดเส้นทางเดินรถแบบเปิดเพื่อลด ต้นทุนการขนส่ง}

อรประไพ จารุพัฒน์ ${ }^{* \star *}$ และ ปวีณา เชาวลิตวงศ์

สาขาวิชาวิศวกรรมอุตสาหการ คณะวิศวกรรมศาสตร์ จุฬำลงกรณ์มหาวิทยาลัย กรุงเทพมหานคร 10330 ประเทศไทย อีเมล์: onprapai.j@student.chula.ac.th ${ }^{\mathrm{a}, *}$, paveena.c@chula.ac.th ${ }^{\mathrm{b}}$

บทคัดย่อ การจัดเส้นทางเดินรถแบบเปิดเป็นแนวทางหนึ่งในการลดต้นทุนขนส่งของลักษณะการขนส่งจากสถานที่รับ-ส่ง สินค้าต่างๆ ที่ตั้งอยู่อย่างกระจายเป็นระยะทางที่ห่างไกลกัน โดยที่รูปแบบของเส้นทางขนส่งไม่จำเป็นต้องมีจุดเริ่มต้นและ สิ้นสุดการทำงานเป็นจุดเดียวกันดังเช่นปัญหาการจัดเส้นทางขนสงทั่วไป ซึ่งความแตกต่างนี้ทำให้การจัดรูปแบบการเดินรถ แบบเปิดสามารถทำงานได้อย่างต่อเนื่องโดยที่ไม่ต้องกลับไปเริ่มต้นเส้นทางที่สถานที่ตั้งต้นเดิมเสมอ (Home Base) งานวิจัยนี้จึงมีวัตถุประสงค์เพื่อพัฒนาฮิวริสติกสำหรับปัญหาการจัดเส้นทางเดินรถแบบเปิดที่ต้องมีการรับและส่งสินค้า ภายใต้กรอบเวลากำหนดการสงมอบและข้อจำกัดความจุในการบรรทุกของรถขนส่งเพื่อให้ได้ระยะทางขนส่งรวมที่สั้นที่สุด ฮิวริสติกที่นำเสนอพัฒนามาจากวิธีการ Insertion Heuristic ซึ่งเป็นวิธีการจัดเส้นทางที่ไม่ซับซ้อนและเหมาะสำหรับการจัด เส้นทางที่ต้องคำนวณแทรกงานขนส่งใหม่ลงเส้นทางเดิมได้อย่างรวดเร็ว ในการทดสอบฮิวริสติกกับปัญหาตัวอย่างพบว่า เมื่อเปรียบเทียบต้นทุนการขนส่งที่ได้จากฮิวริสติกที่นำเสนอกับวิธีการจัดเส้นทางแบบอื่น คือ วิธีการ Nearest Neighbor พบว่า การจัดเส้นทางเดินรถแบบเปิดด้วยวิธี Insertion Heuristic ให้คำตอบที่ดีกว่าโดยเฉลี่ย $6.51 \%$ และผลลัพธ์ที่ได้ให้ค่า ต้นทุนที่ต่ำกว่าในทุกลักษณะของตัวอย่างการขนสงที่สร้างขึ้นจากความต้องการขนสงจริง ดังนั้นจึงสรุปได้ว่าฮิวริสติกที่ นำเสนอสามารถนำไปหาคำตอบของปัญหาการจัดเส้นทางเดินรถแบบเปิดได้อย่างมีประสิทธิภาพ

คำสืบค้น: การจัดเส้นทางเดินรถแบบเปิด, ฮิวริสติก, การแทรกงาน

วารสารวิศวกรรมศาสตร์ (ISSN: 1906-3636) ปีที่ 4 ฉบับที่ 3

วันที่สง 23 มกราคม 2556

วันที่ตอบรับ 8 พฤษภาคม 2556

วันที่ตีพิมพ์ 31 พฤษภาคม 2556

Online at http://www.ej.eng.chula.ac.th/

DOI:10.4186/ejth.2012.4.3.57 


\title{
Heuristic for Open Vehicle Routing Problem to Reduce
} Transportation Cost

\author{
Onprapai Jaruphat ${ }^{a{ }^{a} \star}$ and Paveena Chaovalitwongse ${ }^{b}$
}

Department of Industrial Engineering, Faculty of Engineering, Chulalongkorn University, Bangkok 10330, Thailand

E-mail: onprapai.j@student.chula.ac.th ${ }^{a, *}$, paveena.c@chula.ac.th ${ }^{b}$

\begin{abstract}
The open vehicle routing (OVR) is an approach toward transportation cost reduction, especially for long distance pickup and delivery nodes. The outstanding characteristic of OVR is that the route starting node and ending node are not necessary the same as in typical vehicle routing problems. This advantage enables the routing to flow continuously and the vehicle does not always return to its home base. This research aims to develop a heuristic for the open vehicle routing problem with pickup and delivery under time window and loading capacity constraints to minimize the total distance. The proposed heuristic is developed based on the Insertion method, which is a simple method and suitable for the rapid calculation that allows insertion of the new additional transportation requirements along the original paths. According to the heuristic analysis, cost comparisons between the proposed heuristic and an alternative method, nearest neighbor method, show that the insertion heuristic gave an average of $6.51 \%$ in cost savings. Moreover, the proposed heuristic gave superior solutions in all types of test problems. In conclusion, the proposed heuristic can effectively and efficiently solve the open vehicle routing.
\end{abstract}

Keywords: Open vehicle routing, heuristic, insertion.

Engineering Journal (ISSN: 1906-3636) Volume 4 Issue 3

Received 23 January 2013

Accepted 8 May 2013

Published 31 May 2013

Online at http://www.ej.eng.chula.ac.th/

DOI:10.4186/ejth.2012.4.3.57 


\section{1. บทนำ}

ปัจจุบันการขนส่งมีความสำคัญต่อธุรกิจทั้งในส่วนของการจัดหาวัตถุดิบ การผลิต และการจัดจำหน่าย ในหลายธุรกิจต้นทุน การขนส่งนับเป็นต้นทุนที่สำคัญและกระทบต่อต้นทุนรวมของสินค้า [1] การลดต้นทุนค่าขนส่งโดยการวางแผนเส้นทางเดิน รถที่เหมาะสมจึงเป็นแนวทางหนึ่งที่ถูกเลือกมาใช้ในอุตสาหกรรม เพื่อลดต้นทุนรวมของสินค้า ทั้งนี้การลดต้นทุนขนส่ง จำเป็นต้องมีการปรับเปลี่ยนวิธีการขนส่งเพื่อให้มีระยะทางรวมลดลง การขนส่งแบบปลายเปิดนี้ (Open Vehicle Routing) เป็นการวางแผนเส้นทางเดินรถที่ไม่จำเป็นจะต้องกลับมายังจุดปล่อยรถตอนเริ่มต้นของแต่ละรอบการขนส่ง โดยที่รถขนส่ง สามารถเริ่มต้นเส้นทางใหม่ได้จากจุดขนส่งของลูกค้ารายสุดท้าย

ลักษณะของการขนส่งในงานวิจัยนี้คือ เป็นการขนส่งที่มีจุดปล่อยรถมากกว่า 1 แห่ง และทำการขนส่งสินค้าจากหลาย แห่งไปตามจุดต่างๆ ที่มีระยะห่างกันออกไป และความต้องการขนส่งสินค้าอาจมีการเปลี่ยนแปลงเมื่อเวลาผ่านไปซึ่งจะต้อง ทำการปรับเส้นทางให้รองรับกับการเปลี่ยนแปลงที่เกิดขึ้นในแต่ละรอบ ซึ่งการวางแผนเส้นทางเดินรถแบบเปิดเป็นประโยชน์ ต่อลักษณะการขนส่งดังกล่าว เพราะสามารถลดต้นทุนขนสงจากการลดระยะทางเดินทางย้อนกลับจุดเริ่มต้นของรถขนส่งแต่ ละรอบที่เป็นระยะทางไกลและมีความยืดหยุ่นในการปรับเปลี่ยนเส้นทาง เพราะเส้นทางขนส่งมีความเป็นอิสระที่สามารถ เริ่มต้นต่อได้ทันที่โดยไม่ต้องย้อนกลับไปยังจุดปล่อยรถ ทำให้ประหยัดค่าการเดินทางที่เพิ่มขึ้นของระยะทางใหม่จากการ ปรับเส้นทาง

จากการศึกษางานวิจัยที่เกี่ยวข้องกับปัญหาเส้นทางเดินรถแบบเปิดโดยทั่วไป [2-5] พบว่า เป็นการจัดเส้นทางของ ปัญหาการส่งสินค้าอย่างเดียว เช่น ปัญหาการกระจายสินค้าจากศูนย์กระจายสินค้าไปยังลูกค้ารายต่างๆ อย่างไรก็ตามใน การขนส่งสามารถมีได้ทั้งการรับและการส่งสินค้าไปพร้อมกันในหนึ่งเส้นทาง ซึ่งเป็นสิ่งที่เกิดขึ้นจริงในการขนส่งปัจจุบันที่ จะต้องทำการวางแผนเส้นทางให้เหมาะสมและมีต้นทุนต่ำโดยเป็นรูปแบบปัญหาที่ผู้วิจัยสนใจนำมาศึกษาต่อ เนื่องจากว่า ปัญหาการจัดเส้นทางขนส่งแบบเปิดจัดเป็นปัญหาที่ซับซ้อนยากต่อการหาคำตอบที่ดีที่สุด (NP-Hard) ซึ่งต้องใช้เวลานาน [6-7] ดังนั้นผู้วิจัยจึงนำเสนอฮิวริสติกของการจัดเส้นทางเดินรถแบบเปิดในการแก้ปัญหารับ-ส่งสินค้าพร้อมกันบนเส้นทาง และสำหรับข้อมูลรับเข้าใหม่ที่เปลี่ยนแปลงไป เพื่อลดต้นทุนการขนส่งรวม

\section{2. งานวิจัยที่เกี่ยวข้อง}

ปัญหาการจัดเส้นทางเดินรถโดยพื้นฐานคือ การพิจารณาหาเส้นทางลำดับการส่งสินค้าของรถแต่ละคันจากจุดปล่อยรถแห่ง เดียวหรือหลายแห่ง เพื่อให้ลูกค้าทุกรายได้รับสินค้าภายใต้กรอบเวลาที่กำหนด โดยปัญหาการจัดเส้นทางมีหลากหลาย รูปแบบแตกต่างกันไปตามวัตถุประสงค์และข้อจำกัดของระบบที่ผู่ศึกษาสนใจ [8-9] เช่น Capacitated Vehicle Routing Problem, Multi-Depot Vehicle Routing Problem เป็นต้น ถ้าแบ่งประเภทของการจัดเส้นทางเดินรถตามลักษณะการ เดินทางจะสามารถแบ่งออกได้เป็น 2 ประเภทใหญ่ [5] คือ เส้นทางเดินรถแบบปิด (Closed Trips หรือ Vehicle Routing Problem) คือ รถแต่ละคันต้องออกและกลับมาสูจุดปล่อยรถเดิม ในขณะที่เส้นทางเดินรถแบบเปิด (Open Vehicle Routing Problem) คือ รถขนส่งไม่ต้องย้อนกลับมายังจุดปล่อยรถหลังจากส่งสินค้าให้กับลูกค้ารายสุดท้าย ซึ่งการจัดเส้นทางเดินรถ แบบเปิดมีวัตถุประสงค์เพื่อลดต้นทุนการขนส่งรวม เพราะลดระยะเดินทางย้อนกลับโดยเฉพาะอย่างยิ่งถ้ามีการขนส่งหลาย คันจะทำให้ประหยัดระยะทางโดยรวมลงได้มาก เช่นเดียวกับงานวิจัยนี้ที่มีจุดปล่อยรถหลายแห่งที่ตั้งห่างกันไป ตัวอย่างเช่น รูปที่ 1 การส่งสินค้าไปยังจุดต่างๆใช้รถ 2 คันออกจากจุดปล่อยรถ 1 และ 3 ซึ่ง (a) เส้นทางแบบปิดได้ระยะทางรวม 10.5 
ส่วน (b) เส้นทางแบบเปิดมีระยะทางรวม 5.2 เนื่องจากสามารถหยุดที่จุดสุดท้ายของเส้นทาง (R1 จอดที่ 3 และ $R 2$ จอดที่ 6) โดยไม่ต้องเดินทางกลับมายังจุดเริ่มต้น (3 กลับ 1 และ 6 กลับ 3) ซึ่งมีระยะทางไกล

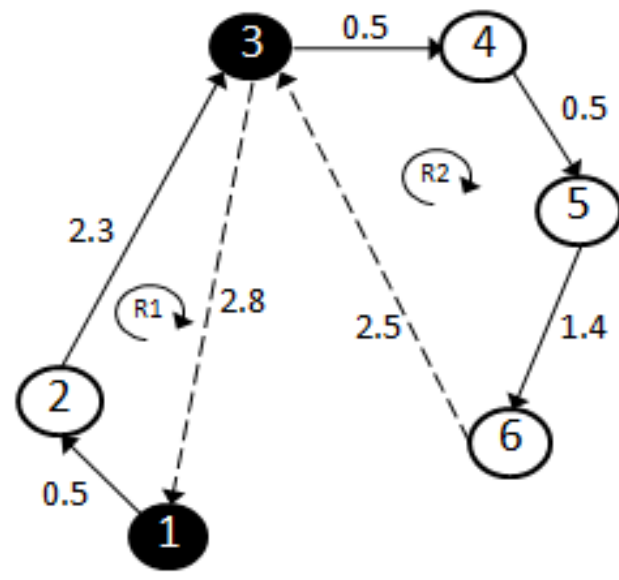

(a)

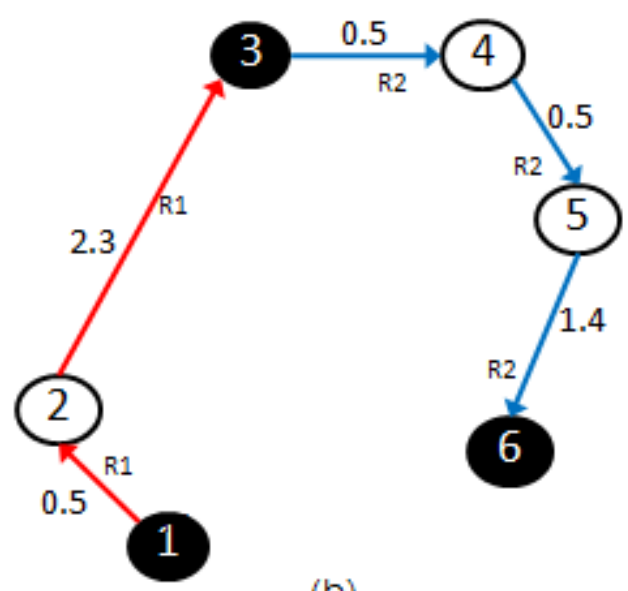

(b)

รูปที่ 1 (a) เส้นทางแบบปิด VRP, (b) เส้นทางแบบเปิด OVRP

ปัญหาการจัดเส้นทางเดินรถแบบเปิดที่พบในงานวิจัยที่ผ่านมามีลักษณะการขนส่งสินค้าที่เป็นแบบแผน คือ ออกจาก จุดปล่อยรถอย่างเดียวหรือเป็นการรับสินค้าเพียงอย่างเดียวตลอดเส้นทางในแต่ละรอบ [4] เช่น Bodin และคณะ ซึ่งได้ ศึกษาการขนส่งสินค้าทางเครื่องบินของ FedEx ที่เครื่องบินออกจากเมืองหนึ่งไปส่งสินค้ายังเมืองต่างๆ และจอดลงที่เมือง สุดท้ายของเส้นทางส่งสินค้าและเริ่มทำการรับสินค้าอีกครั้งจากเมืองที่ลงจอด สำหรับ Russell และคณะ ได้ศึกษาการส่ง สินค้าและการส่งหนังสือพิมพ์ตามบ้าน ในขณะที่ $\mathrm{Fu}$ และคณะ ศึกษาการวางแผนเส้นทางรถรับ-ส่งนักเรียน เป็นต้น ซึ่งใน สถานการณ์จริงของการขนส่งนั้นบนเส้นทางที่รถขนส่งผ่านจุดหนึ่งๆ จะสามารถมีได้ทั้งการรับและส่งสินค้า ดังนั้นเส้นทาง ขนส่งที่จะทำให้มีต้นทุนการขนส่งต่ำจึงสามารถเป็นได้ในการรับและส่งสินค้าพร้อมกันในเส้นทางแต่ละรอบ และอีก สถานการณ์หนึ่งที่เป็นอยู่ของคำสั่งการขนส่งสินค้าคือ เป็นการรับทราบข้อมูลล่วงหน้า ข้อมูลงานขนส่งที่รับเข้าสามารถมี การเปลี่ยนแปลงไปตามเวลาที่เรียกว่า ปัญหาแบบพลวัต (Dynamic) และมีการเพิ่มเข้าของข้อมูลความต้องการขนส่งที่ ทราบระหว่างการจัดเส้นทาง ดังนั้นจากสถานการณ์การขนส่งจริงที่เกิดขึ้นดังกล่าวจึงเป็นสิ่งที่ผู้วิจัยสนใจศึกษาและนำมา กำหนดรูปแบบปัญหาเส้นทางขนส่งของงานวิจัยนี้ในส่วนถัดไปเพื่อให้เหมาะสมกับการจัดเส้นทาง

\section{3. รูปแบบปัญหา}

งานวิจัยนี้เป็นการรวมกันของ 3 รูปแบบปัญหาการจัดเส้นทางเดินรถ ได้แก่ (1) การนำแนวคิดการจัดเส้นทางขนส่งแบบเปิด (Open Vehicle Routing Problem) มาประยุกต์ใช้กับการวางแผนเส้นทางขนส่งของเครือข่ายธุรกิจของโรงงานอุตสาหกรรม ที่ตั้งอยู่ตามภูมิภาคต่างๆที่มีความจำเป็นในการขนส่งระหว่างกัน ซึ่งทำให้มีจุดปล่อยรถหลายแห่งและมีเวลาเริ่มต้นไม่พร้อม กันรวมถึงเป็นการจัดเส้นทางของรถหลายคันพร้อมกัน โดยมีวัตถุประสงค์การจัดเส้นทางเพื่อลดต้นทุนการขนส่งรวม ซึ่ง เส้นทางขนส่งที่สร้างขึ้นอยู่ในรูปแบบการขนส่งอย่างต่อเนื่องที่รถขนส่งสามารถทำงานได้ตลอดเวลาและสามารถเริ่มต้น ณ ที่จุดใดก็ได้ โดยไม่จำเป็นจะต้องกลับมายังจุดเริ่มต้นเสมอทุกครั้ง จึงทำให้เกิดเส้นทางขนส่งสินค้าที่เป็นไปได้จำนวนมาก และการเลือกเส้นทางที่ดีที่สุดจึงจัดเป็นปัญหาระดับยากและใช้เวลานานในการหาคำตอบที่ดีสุด [6-7] (2) กิจกรรมการ ขนส่งที่เกิดขึ้นในแต่ละเส้นทางเป็นทั้งรับและสงสินค้า (Pickups and Deliveries) พร้อมกันโดยไม่มีรูปแบบที่แน่นอน 
ตัวอย่างดังรูปที่ 2 แสดงลักษณะเส้นทางเดินรถแบบเปิดของงานวิจัยที่มีจุดเริ่มต้นเส้นทางหลายแห่ง จุดขนส่งบนเส้นทางแต่ ละจุดนั้นสามารถมีรถได้มากกว่า 1 คัน ในการแวะมารับและ/หรือสงงสินค้า ซึ่งในการจัดเส้นทางรับและสงสินค้าพร้อมกัน จะต้องทำพิจารณาคู่ใหนดรับ-ส่งของทุกงานขนส่งบนเส้นทางในรถแต่ละคันให้สามารถดำเนินการขนส่งได้ทั้งหมด ภายใต้ ข้อจำกัดการจัดเส้นทางของความจุรถ (Loading Capacity) และกรอบเวลากำหนดส่งมอบ (Time Window) ทำให้เกิดเป็น ปัญหาที่มีความซับซ้อนมากยิ่งขึ้นในการจัดเส้นทางเดินรถ

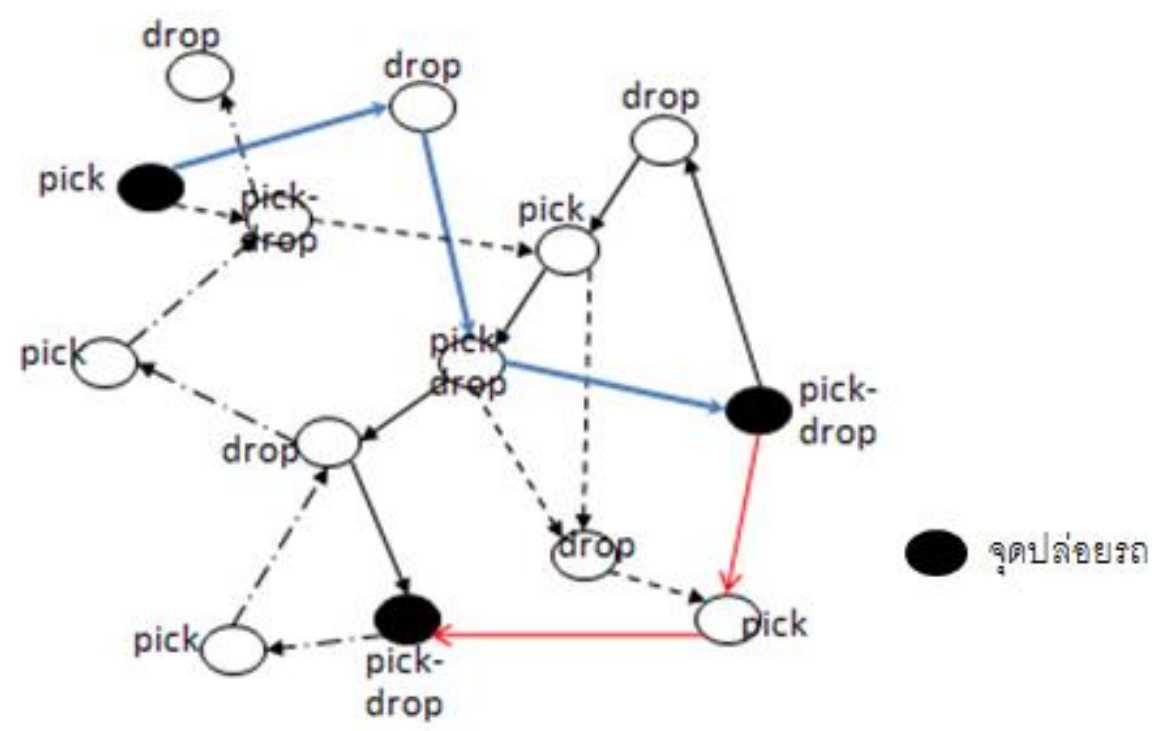

รูปที่ 2 เส้นทางเดินรถแบบเปิดรับและส่งสินค้า

ทั้งนี้ข้อมูลที่เกิดขึ้นจะเป็นทั้งความต้องการให้รับสินค้าจากแห่งหนึ่งและความต้องการนำส่งสินค้าไปยังอีกแห่งหนึ่ง จึงมีการ กำหนดส่งมอบเป็นช่วงเวลาเริ่มต้นรับสินค้า (Earliest Time) ถึงเวลาช้าสุดที่ส่งสินค้าได้ (Latest Time) และ 3) อีกทั้งข้อมูล ความต้องการขนส่งเป็นข้อมูลอนาคตที่สามารถเปลี่ยนแปลงได้ (Dynamic Transportation Requirements) จึงต้องทำการ ปรับแผนเส้นทางเดินรถ (Rolling) ทุกครั้งที่มีข้อมูลใหม่ เช่น เดินรถขนส่งถูกกำหนดเส้นทาง A-B-C-D เมื่อเวลาผ่านไปมี ความต้องการขนส่งใหม่ที่ต้องรับสินค้าจากโหนด $E$ เพื่อนำไปส่งที่โหนด $D$ การจัดเส้นทางรอบใหม่ทันทีโดยปรับจากเส้นทาง เดิมได้เป็น $A-B-E-C-D$ เพื่อให้ทุกความต้องการขนส่งสามารถดำเนินการขนส่งสินค้าได้ทันเวลาพอดี นอกจากนี้สินค้าที่ ศึกษาในงานวิจัยนี้ยังมีลักษณะหลากหลาย เช่น สินค้าขนาดใหญ่น้ำหนักเบา สินค้าขนาดใหญ่น้ำหนักมาก หรือสินค้าขนาด เล็กน้ำหนักมาก เป็นต้น จึงต้องมีการพิจารณาความต้องขนส่งทั้ง 2 มิติ คือ ปริมาตร และน้ำหนัก เนื่องจากว่าในงานวิจัยนี้มี การกำหนดจุดปล่อยรถหลายแห่งจึงมีเส้นทางเดินรถเป็นจำนวนมาก โดยภาพรวมวัตถุประสงค์ของงานวิจัยนี้ต้องการลด ต้นทุนการขนส่งรวม เพราะฉะนั้นเกณฑ์ที่ใช้พิจารณาเส้นทางขนส่งจะเป็นต้นทุนการขนสงที่เกิดขึ้นจากเส้นทางทั้งหมด รวมกันที่มีค่าต่ำสุด โดยการจัดเส้นทางเดินรถต้องอยู่ภายใต้ข้อจำกัด คือ

- ข้อจำกัดของรถขนส่งด้านความจุของรถขนส่ง (Capacity Constraint)

- ข้อจำกัดของงานขนส่งด้านกรอบเวลาในการรับส่งสินค้า (Time Window Constraint)

โดยมีขอบเขตและข้อกำหนดของงานวิจัยดังนี้

- ความต้องการของงานขนส่งสินค้าจะต้องไม่เกินความจุรถ

- ไม่สามารถแยกสินค้า (Split Order) เพื่อขนส่งได้ 
- ไม่สามารถพัก (Cross Docks) หรือ ถ่ายโอนสินค้า (Transshipment) ได้

- เวลาโหลดสินค้าไม่ถูกนำมาพิจารณา

- ทุกโหนดในระบบสามารถเป็นจุดพักรถขนส่งได้

ดังนั้นปัญหาการจัดเส้นทางขนส่งของงานวิจัยนี้เป็นรูปแบบของข้อมูลงานขนส่งพลวัต (Dynamic) ที่มีความไม่แน่นอน ของข้อมูลและไม่สามารถคาดการณ์ความต้องการขนส่งที่เกิดขึ้นในอนาคตได้ เช่น งานขนส่งมีการเปลี่ยนแปลงเวลากำหนด ส่งมอบ เป็นต้น ฉะนั้นจึงต้องมีการปรับเส้นทางทุกครั้งที่มีการเปลี่ยนแปลงของข้อมูล (Rolling) ซึ่งรูปแบบเส้นทางจาก วิธีการของการจัดเส้นทางเดินรถแบบเปิด (OVRP) เหมาะสมสำหรับการแก้ปัญหานี้ เพราะรถขนส่งมีความเป็นอิสระในการ เปลี่ยนเส้นทางได้อย่างรวดเร็ว เนื่องจากคุณลักษณะเด่นของวิธีการจัดเส้นทางเดินรถแบบเปิดที่ไม่ต้องให้รถกลับมายังจุด ปล่อยรถนั่นเอง ในส่วนของการหาคำตอบของการจัดเส้นทางขนส่ง แบบเปิด งานวิจัยส่วนใหญ่ที่เกี่ยวข้อง [2-5] จะแก้ไข ปัญหาด้วยวิธีการฮิวริสติกที่ให้ค่าของผลคำตอบที่ดีและใช้เวลาคำนวณน้อย เนื่องจากปัญหาการจัดเส้นทางเดินรถแบบเปิด ถือได้ว่าเป็นปัญหาระดับยากและซับซ้อน (NP-Hard) จากการศึกษาของ Brandao (2004) และ Laporte (2009) [6-7] ดังนั้นการหาคำตอบที่ดีที่สุดจะต้องใช้เวลานาน ฉะนั้นในงานวิจัยนี้ได้นำเสนอฮิวริสติกในส่วนถัดไปเพื่อใช้ในการหาคำตอบ

\section{4. หลักการและแนวคิดของฮิวริสติก}

จากที่กล่าวข้างต้นปัญหาการจัดเส้นทางเดินรถของงานวิจัยนี้เป็นปัญหาการจัดเส้นทางเดินรถแบบเปิด (Open Vehicle Routing Problem) ที่มีข้อมูลแบบพลวัต (Dynamic) รวมอยู่ด้วย ซึ่งแนวคิดของฮิวริสติกสำหรับงานวิจัยนี้จึงเกี่ยวข้องกับ ปัญหาทั้ง 2 รูปแบบตามลำดับดังนี้ ปัญหาการจัดเส้นทางแบบเปิดซึ่งได้ศึกษาและรวบรวมแนวทางการหาคำตอบของ MirHassani และ Abolghasemi (2011) [2] และ Zachariadis และ Kiranoudis (2010) [3] ซึ่งได้นำเสนอวิธีฮิวริสติกที่ถูก พัฒนาขึ้นมาเป็นลำดับจากวิธีการแบบดั้งเดิม เช่น Savings Heuristic ของ Clarke and Wright, Cluster First Route Second, Tabu Search เป็นต้น จนถึงวิธีการหาคำตอบแบบผสมผสาน (Meta-Heuristic) เช่น Farthest-First Heuristic และปรับปรุงคำตอบด้วยวิธีการของ Tabu Search หรือวิธีการของ Ant Colony Optimization ร่วมกับ Tabu Search เป็น ต้น ซึ่งจากการศึกษางานวิจัยที่ผ่านมาสำหรับ Meta-Heuristic นั้นวิธีการหนึ่งที่ใช้สร้างเส้นทางเบื้องต้น คือ Insertion และ จากงานวิจัยของ Berbeglia และคณะ (2010) [10] ที่ศึกษารวบรวมเกี่ยวกับปัญหาการรับและส่งสินค้าแบบพลวัต (Dynamic Pickup And Delivery Problems) พบว่า การจัดเส้นทางเดินรถสำหรับข้อมูลที่มีการเปลี่ยนแปลงไปตามเวลา หรือแทรกเพิ่มเข้ามา โดยส่วนมากจะแก้ปัญหาด้วยวิธีการ Insertion ดังนั้นผู้วิจัยจึงนำแนวคิดวิธีการ Insertion Heuristic มาประยุกต์ใช้สำหรับการวางแผนเส้นทางเดินรถปลายเปิดของงานวิจัยนี้ที่มีวัตถุประสงค์เพื่อลดต้นทุนการขนส่งรวม เพราะ วิธีการแทรกงานขนส่ง เป็นการหาเส้นทางที่จะสามารถขนสงสินค้าที่เพิ่มเข้ามาใหม่ได้อย่างรวดเร็วและอยู่บนเส้นทางที่ กำหนดไว้แล้วหรือมีการเปลี่ยนแปลงน้อยมาก เพื่อยังคงให้มีระยะทางต่ำตามที่คำนวณไว้ก่อนหน้าโดยไม่มีการปฏิเสธงาน ขนส่ง

การจัดเส้นทางขนส่งจะต้องทำการพิจารณาเลือกงานขนส่งและจัดลงเส้นทางของรถคันใดจึงจะได้ระยะทางรวมต่ำที่สุด ในงานวิจัยนี้ผู้วิจัยจึงแบ่งขั้นตอนการพิจารณาการจัดเส้นทางขนส่งออกเป็น 2 ขั้นตอน คือ การเลือกงานขนส่งและการจัด เส้นทาง (ดังแสดงตามรูปที่ 3) 


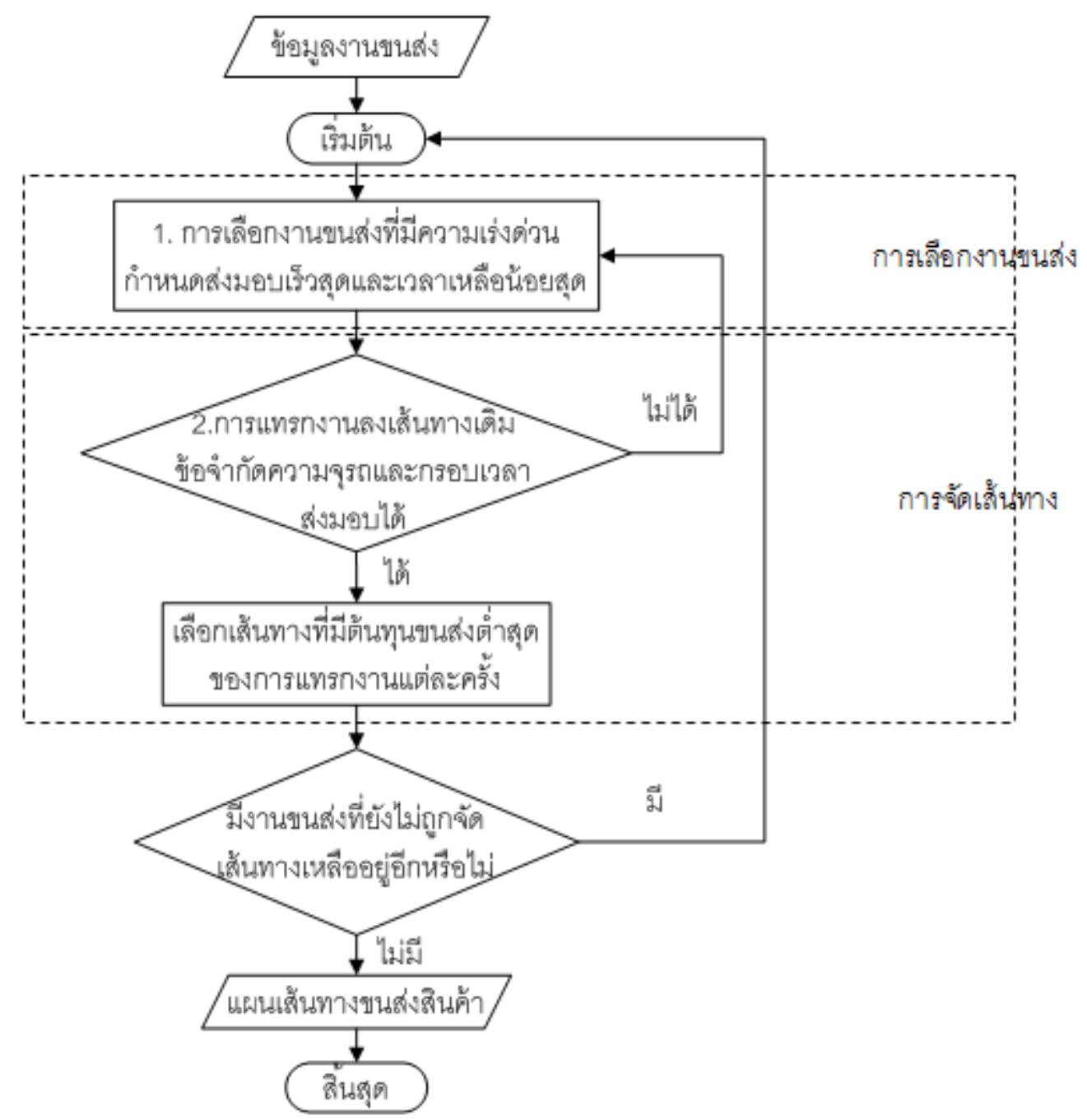

รูปที่ 3 ภาพรวมกระบวนการจัดเส้นทางขนส่งสินค้า

ในการจัดเส้นทางที่มีข้อมูลงานขนส่งจำนวนมากและมีเวลากำหนดส่งมอบที่แตกต่างกันแต่ในขณะที่จำนวนรถขนส่งที่ ใช้ในการปฏิบัติงานนั้นมีอยู่ด้วยจำนวนจำกัด ดังนั้นจึงต้องมีการพิจารณาเลือกงานขนส่งในขั้นตอนแรก เพื่อค้นหางานที่มี ความเร่งด่วนมาทำการจัดเส้นทางก่อน โดยพิจารณาจากกำหนดส่งมอบช้าสุด (Latest Due Date) ที่มีค่าน้อยสุด และ พิจารณาร่วมกับเวลาเหลือ (Slack Time) คือ เวลาที่เหลือเสร็จก่อนกำหนดมีค่าน้อยสุดมาทำการจัดเส้นทางก่อน หลังจาก เลือกงานขนส่งได้แล้วจากขั้นตอนแรก จึงนำงานที่มีความจำเป็นเร่งด่วนมาทำการจัดเส้นทางขนส่ง โดยวิธีการลองแทรกงาน (Insertion) ลงบนรถทุกคัน เพื่อเปรียบเทียบและเลือกเส้นทางขนส่งที่มีค่าระยะทางโดยรวมต่ำสุด ภายใต้ข้อจำกัดความจุรถ และกรอบเวลาในการส่งมอบสินค้า ทำซ้ำทั้งสองขั้นตอนจนกระทั่งงานขนส่งทุกรายการถูกจัดลงบนเส้นทางจึงจะสิ้นสุด กระบวนนการจัดเส้นทางรับสงงสินค้า

สำหรับการจัดเส้นทางปัญหาข้อมูลแบบพลวัต (Dynamic) ในงานวิจัยนี้ การจัดเส้นทางแต่ละครั้งจะมองภาพปัญหา เป็นการทราบข้อมูลทั้งหมดของรอบนั้นก่อนการจัด และเมื่อระบบมีข้อมูลเปลี่ยนแปลงจะคำนวณปรับเส้นทางขนส่ง (Rolling) ทันทีโดยรวมข้อมูลใหม่และข้อมูลเดิมเข้าไว้ด้วยกัน ซึ่งการคำนวณเส้นทางจะนำข้อมูลทั้งหมดที่มีอยู่มาทำการ คำนวณสร้างเส้นทางเดินรถตามวิธีการของฮิวริสติกที่นำเสนอ 


\section{1. การเลือกงานขนส่ง}

จากข้อมูลความต้องการขนส่งในงานวิจัยนี้มีลักษณะที่กำหนดการรับสงสินค้าเป็นช่วงเวลาหนึ่ง ซึ่งมีสมมติฐานว่างานที่มี กำหนดส่งมอบก่อนน่าจะมีความแน่นอนสูง ส่วนงานที่มีกำหนดการส่งมอบช้ากว่าจะยังมีความไม่แน่นอนของข้อมูลและ อาจมีการเปลี่ยนแปลงคำสั่งรับส่งสินค้าได้ ในขั้นตอนการเลือกงานขนส่งนี้มีวัตถุประสงค์ คือ การเลือกงานขนส่งจำนวน 1 งาน เพื่อนำไปพิจารณาแทรกงานในขั้นตอนต่อไปและเลือกงานที่มีความเร่งด่วนมากทำการจัดเส้นทางก่อน เพื่อให้ความ ต้องการขนส่งทั้งหมดในระบบสามารถขนส่งได้ทันเวลาพอดี โดยการหาความเร่งด่วนของงานพิจารณาประยุกต์จาก 2 กฏ การจ่ายงาน คือ กำหนดสงมอบเร็วที่สุด (Earliest Due Date หรือ EDD) เป็นเกณฑ์หลัก ผลจากการเลือกงานขนส่งจาก เวลาส่งมอบสามารถเกิดขึ้นได้ 2 กรณีคือ เลือกงานขนส่งได้จำนวน 1 งาน กรณีนี้งานขนส่งจะสามารถนำไปจัดเส้นทางต่อ ในกระบวนการถัดไปได้ทันที สำหรับในกรณีที่ 2 จากการพิจารณาเวลาสงมอบเร็วสุดถ้าเกิดมีงานขนส่งที่มีกำหนดส่งมอบ เท่ากันมากกว่า 1 งาน จะต้องเลือกงานโดยใช้เกณฑ์รอง คือ กฏการจ่ายงานของเวลาเหลือก่อนจะถึงกำหนดส่งมอบน้อยสุด (Minimum Slack Time หรือ MST) เพื่อคัดเลือกงานขนส่งจำนวน 1 งานที่มีความเร่งด่วนมากกว่าไปทำการจัดเส้นทางก่อน โดยกระบวนการเลือกงานขนส่งแสดงดังรูปที่ 4

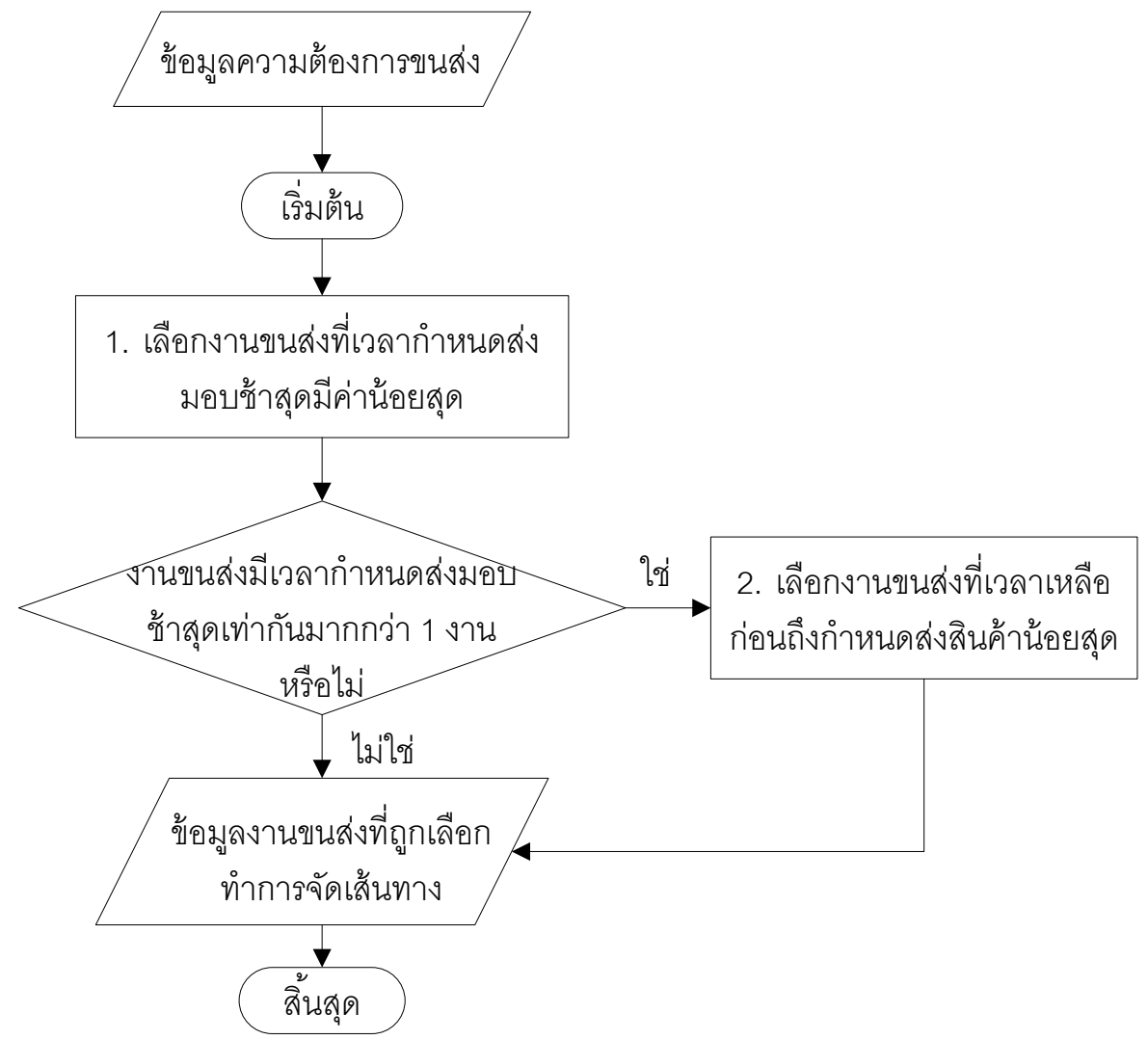

รูปที่ 4 ขั้นตอนการเลือกงานขนสง

วิธีการคำนวณในขั้นตอนการเลือกงานขนส่งดังนี้

1. เลือกงานขนส่งจากเวลากำหนดส่งมอบตามกฏการจัดลำดับแบบ $E D D$ ซึ่งจะเรียงลำดับของงานโดยกำหนด ส่งมอบจากน้อยไปมาก $\mathrm{d}_{[1]} \leq \mathrm{d}_{[2]} \leq \ldots \leq \mathrm{d}_{[\mathrm{n}]}$ โดยที่ $\mathrm{d}_{[\mathrm{n}]}$ คือ กำหนดส่งมอบ (Due Date) ของงานขนส่ง ใดๆ [11] แต่สำหรับงานวิจัยนี้ได้พิจารณากำหนดส่งมอบจากข้อมูลเวลาสงสินค้าช้าสุด (Latest Due Date) โดยงานขนส่งใดที่มีค่า Latest Time $\left(\mathrm{L}_{\mathrm{i}}\right)$ น้อยสุดจะถูกเลือกเป็นอันดับแรก $\mathrm{L}_{1} \leq \mathrm{L}_{2} \leq \ldots \leq \mathrm{L}_{\mathrm{n}}$ 
ตามลำดับ ซึ่งงานขนส่งที่ถูกเลือกนั้นจะถูกจัดเส้นทางทีละรายการ ถ้าหากมีงานขนส่งที่มีกำหนดเวลาส่งมอบ เท่ากันให้ทำการพิจารณาเลือกงานขนส่งต่อในขั้นตอนที่ 2 เพื่อค้นหางานที่มีความจำเป็นเร่งด่วนมากกว่าใน การขนส่ง

2. การเลือกงานขนส่งจากเวลาเหลือ (Slack Time) ตามกฏการจัดลำดับแบบ MST ซึ่งจะเรียงลำดับของงานจาก เวลาที่เหลือก่อนจะถึงกำหนดส่งมอบจากน้อยไปมาก $\mathrm{d}_{[1]}-\mathrm{p}_{[1]} \leq \mathrm{d}_{[2]}-\mathrm{p}_{[2]} \leq \ldots \leq \mathrm{d}_{[\mathrm{n}]}-\mathrm{p}_{[\mathrm{n}]}$ โดยที่ $\mathrm{p}_{[\mathrm{n}]}$ คือ เวลาดำเนินการขนส่งของงานใดๆ [11] โดยงานที่มีค่าเวลาเหลือน้อยกว่าจะเป็นงานที่มีความ เร่งด่วนมาก สำหรับงานวิจัยได้คำนวณเวลาเหลือ (Slack Time) ตามสมการ (1)

$$
\mathrm{S}_{\mathrm{i}}=\mathrm{L}_{\mathrm{i}}-\mathrm{t}_{\mathrm{i}}-\max \left(\mathrm{E}_{\mathrm{i}}, \min \mathrm{F}_{\mathrm{k}}\right) \quad ; \forall \mathrm{i} \in \mathrm{n}, \forall \mathrm{k} \in \mathrm{m}
$$

โดย $\mathrm{S}_{\mathrm{i}}$ คือ เวลาเหลือในการขนส่งของลำดับความต้องการขนส่งที่ $i$

$\mathrm{t}_{\mathrm{i}}$ คือ เวลาเดินทางจากจุดรับไปยังจุดส่งสินค้าของงานขนส่งที่ $\mathrm{i}$

$\mathrm{L}_{\mathrm{i}}$ คือ เวลากำหนดรับส่งช้าสุดของแต่ละงานขนส่งลำดับที่ $\mathrm{i}$

$\mathrm{E}_{\mathrm{i}}$ คือ เวลากำหนดรับส่งเร็วสุดของแต่ละงานขนส่งลำดับที่ $\mathrm{i}$

$\mathrm{F}_{\mathrm{k}}$ คือ เวลาสุดท้ายที่ถูกกำหนดไว้ของรถขนส่งคันที่ $\mathrm{k}$

$\mathrm{n}$ คือ เซตของงานขนส่งสินค้าทั้งหมด

$\mathrm{m}$ คือ เซตของรถขนส่งทั้งหมดที่มีอยู่

\section{2. การจัดเส้นทางขนส่ง}

การจัดเส้นทางขนส่งด้วยวิธีฮิวริสติกที่นำมาประยุกต์ในงานวิจัยนี้คือ การจัดแบบแทรกงาน (Insertion Heuristic) ซึ่งการหา คำตอบของวิธีการนี้ในแต่ละรอบจะทำการค้นหาว่า งานขนส่งที่รอการจัดลงเส้นทางแต่ละจุดรับ-ส่งสามารถแทรกลงใน เส้นทางที่จัดค้างอยู่ได้ในตำแหน่งใดบ้างและแต่ละตำแหน่งมีค่าใช้จ่ายในการแทรกเป็นเท่าใด โดยพยายามแทรกงานขนส่ง ใหม่เข้าไปในเส้นทางที่ทำให้เกิดค่าใช้จ่ายเพิ่มขึ้นน้อยที่สุด [12] อย่างไรก็ตามการสร้างเส้นทางต้องคำนึงถึงข้อจำกัดหลัก ของความจุรถและกำหนดส่งมอบสินค้าให้สามารถเป็นไปได้ด้วย ขั้นตอนของวิธีการคำนวณการจัดเส้นทางของงานวิจัย แสดงดังรูปที่ 5 เป็นการพิจารณาทีละงานขนส่งจากการเลือกตามขั้นตอนที่ 4.1 มาทำการสร้างเส้นทางโดยวิธีการแทรกงาน ลงในตำแหน่งต่างๆ ของเส้นทางเดิมบนรถขนส่งแต่ละคันที่มีอยู่ทั้งหมด ซึ่งทำให้ได้เส้นทางที่เป็นไปได้ที่ผ่านการตรวจสอบ เงื่อนไขข้อจำกัดการจัดเส้นทางทั้งการคำนวณน้ำหนักและปริมาตรที่ขนส่งจะต้องไม่เกินความจุรถ และการคำนวณเวลาที่ มาถึงจุดรับ-ส่งสินค้าจะต้องอยู่ภายในช่วงกำหนดส่งมอบเร็วสุดและช้าสุด ถ้าหากงานขนส่งไม่สามารถผ่านเงื่อนไขความจุ และเวลาส่งมอบได้จะถูกกำหนดให้ดำเนินการขนส่งสินค้ารายการนั้นโดย Outsource แทน จากเส้นทางที่เป็นไปได้จะทำ การตัดสินใจเลือกเพียง 1 เส้นทางจากการคำนวณต้นทุนระยะทางที่เกิดขึ้น โดยเลือกเส้นทางที่มีต้นทุนการขนส่งรวมของรถ ทุกคันต่ำสุดของแต่ละรอบ อัลกอริทึมจะกระทำซ้ำเช่นเดิมจนกระทั่งงานขนส่งทั้งหมดส่งไปยังลูกค้าทุกรายการ กระบวนการ จัดเส้นทางจะสิ้นสุดเมื่อไม่มีงานขนส่งเหลือรอทำการจัดเส้นทางและเมื่อสิ้นสุดกระบวนการจัดเส้นทางขนส่งจะได้ผลลัพธ์ คือ แผนเส้นทางขนส่งสินค้า 


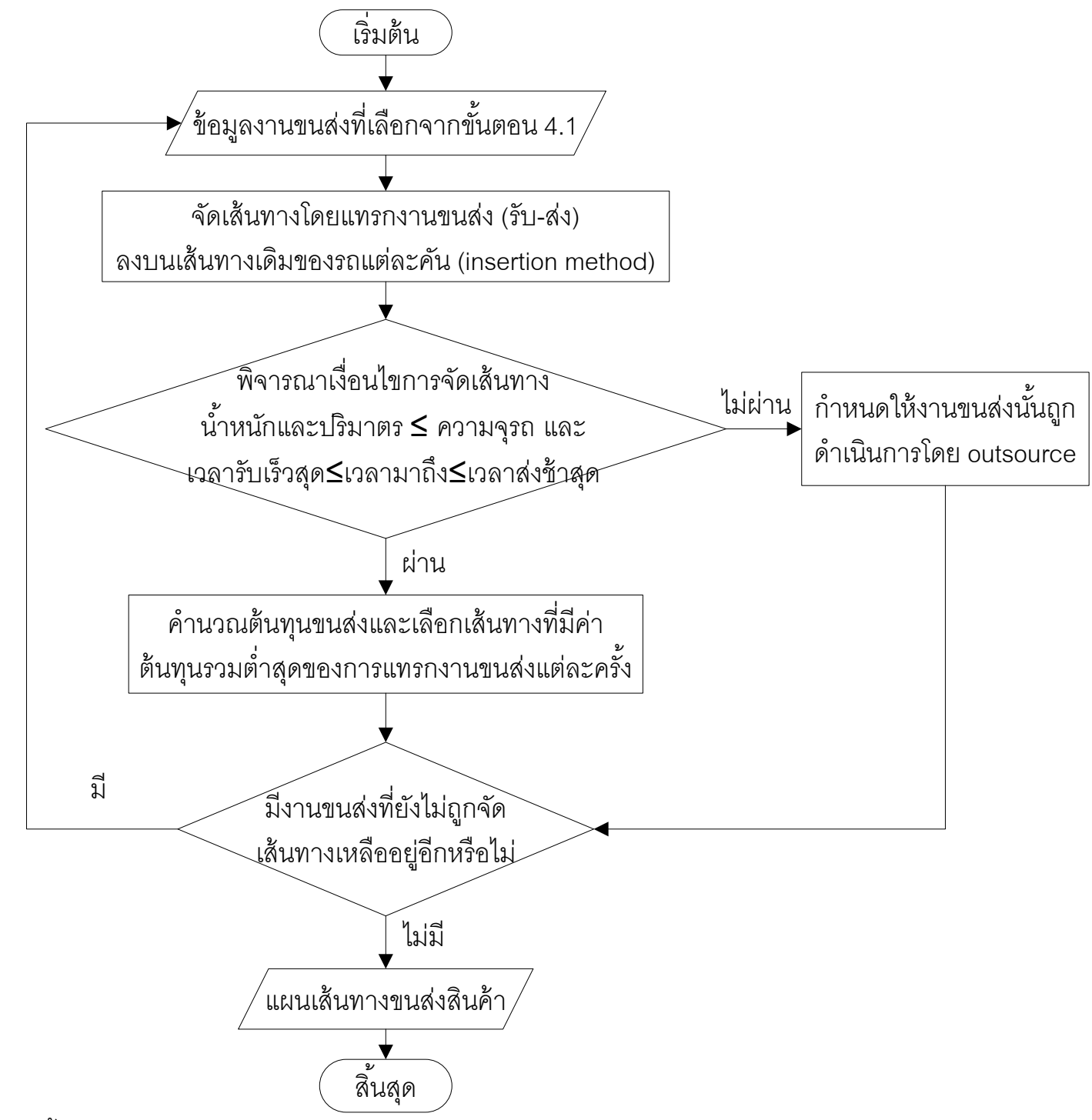

รูปที่ 5 ขั้นตอนการจัดเส้นทางขนส่ง

วิธีการแทรกงานขนส่งลงบนเส้นทาง เป็นการแทรกงานลงบนเส้นทางในตำแหน่งที่เป็นไปได้ทั้งหมด โดยไม่เปลี่ยนแปลง ลำดับงานขนส่งที่ได้จัดวางไว้ก่อนหน้า ซึ่งประยุกต์จากวิธีการของ Nawaz ที่ได้เสนอฮิริสติกที่ใช้งานง่ายและให้คำตอบที่ดี ในกรณีส่วนมาก [11] ตำแหน่งที่สามารถทำการแทรกงานได้จะต่อจากจุดเริ่มต้นของรถในแต่ละรอบและเงื่อนไขของการ แทรก (Insert) จุดรับและส่งสินค้า คือ จุดส่งสินค้าจะต้องอยู่ในตำแหน่งใดๆ หลังจุดรับสินค้าของงานขนส่งนั้น การสร้าง เส้นทางขนส่งโดยวิธีการแทรกงานแสดงตัวอย่างดังรูปที่ 6

การแทรกจุดรับ-ส่งงาน

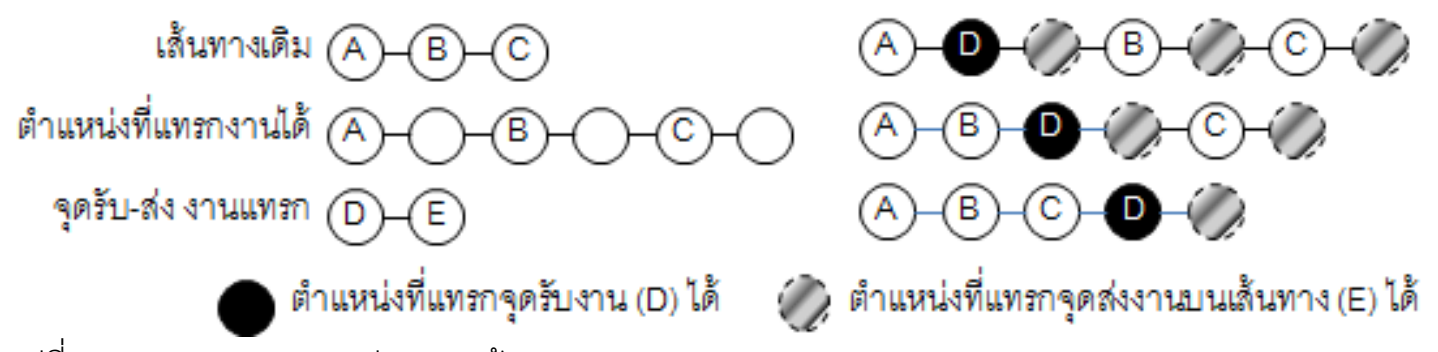

รูปที่ 6 การแทรกงานขนส่งลงบนเส้นทาง 
ตัวอย่างการแทรกงานจากรูปที่ 6 เส้นทางเดิมของรถขนส่งคือ A-B-C และงานขนส่งที่กำลังพิจารณาจัดเส้นทางคือ งาน ขนส่งจาก $D$ ไป $E$ ตำแหน่งที่สามารถแทรกจุดรับสินค้า $D$ ได้คือ หลังโหนด $A, B$ และ $C$ ตำแหน่งที่พิจารณาการแทรกจุดส่ง สินค้าจะเป็นทุกตำแหน่งหลังโหนด $D$ ซึ่งจะเห็นได้ว่าเส้นทางใหม่ที่สร้างขึ้นจากการแทรกงานนั้นจะไม่เปลี่ยนลำดับการเดิน รถของเส้นทางเดิมคือยังคงเป็น $A-B-C$ ตามลำดับ

หลังจากแทรกงานใหม่ลงบนเส้นทางต้องทำการตรวจสอบเงื่อนไขความเป็นไปได้ของเส้นทางที่ต้องผ่านข้อจำกัด เงื่อนไขการจัดเส้นทางเดินรถอันได้แก่ ความจุปริมาตร ความจุน้ำหนัก เวลากำหนดรับสินค้าและเวลากำหนดส่งสินค้า วิธีการคำนวณเงื่อนไขต่างๆ ดังนี้

- ผลรวมของปริมาตรสินค้าที่บรรทุกอยู่บนเส้นทางแต่ละจุดจะต้องไม่เกินความจุปริมาตรรถที่ขนส่งได้

- ผลรวมของน้ำหนักสินค้าที่บรรทุกอยู่บนเส้นทางแต่ละจุดจะต้องไม่เกินน้ำหนักรถที่ขนส่งได้ ซึ่งสินค้าที่จะทำการขนส่งได้จะต้องผ่านทั้งข้อจำกัดปริมาตรและน้ำหนักบรรทุก

- เวลามาถึงแต่ละโหนดต้องไม่น้อยกว่าเวลารับสินค้า ถ้าจุดนั้นเป็นการรับสินค้า และถ้าโหนดนั้นเป็นการส่งสินค้า เวลามาถึงต้องไม่เกินเวลาส่งสินค้าของงานนั้น

ถ้ารถขนส่งมาถึงก่อนเวลารับสินค้าเร็วสุดให้ทำการปรับเวลาที่ตำแหน่งนั้น มีค่าเท่ากับเวลาเร็วสุดที่เริ่มรับสินค้าได้ โดยมีเงื่อนไขของการคอย คือ เวลาที่มาถึงโหนดต่างๆ บนเส้นทางที่เหลือทั้งหมดจะต้องสามารถดำเนินการขนส่งได้ภายใต้ กำหนดส่งมอบของงานนั้นๆ ที่อยู่บนแต่ละโหนด โดยเวลามาถึงแต่ละโหนดคำนวณได้จากเวลาเริ่มต้นจากจุดก่อนหน้ารวม กับเวลาเดินทางระหว่างโหนด

การตัดสินใจในการเลือกเส้นทางขนส่งที่ให้ค่าต้นทุนขนส่งรวมต่ำสุดซึ่งเป็นวัตถประสงค์ของฮิวริสติกในงานวิจัยนี้จาก เส้นทางที่เป็นไปได้ทั้งหมด จะทำการพิจารณาจากการคำนวณต้นทุนการขนส่งรวมจากการแทรกงานใหม่ลงบนเส้นทางเดิม และทำการเปรียบเทียบเส้นทางที่เป็นไปได้ แล้วจึงเลือกเส้นทางที่ให้ค่าต้นทุนขนส่งรวมน้อยสุดของการแทรกงานขนส่งใน รอบนั้น โดยต้นทุนการขนส่งในงานวิจัยนี้พิจาณาเฉพาะต้นทุนแปรผันของระยะทาง วิธีการคำนวณต้นทุนเป็นผลมาจาก ผลรวมระยะทางระหว่างระยะทางของเส้นทางเดินรถใหม่หลังการแทรกงานรวมกับระยะทางของเส้นทางขนส่งเดิมของรถคัน อื่นที่ไม่ได้ทำการแทรกงาน ตัวอย่างการคำนวณแสดงตารางที่ 1

ตารางที่ 1 ตัวอย่างการคำนวณต้นทุนการขนส่งจากการแทรกงาน

\begin{tabular}{|c|c|c|c|}
\hline รถคันที่ (k) & แทรกงานลงบนรถคันที่ 1 & แทรกงานลงบนรถคันที่ 2 & แทรกงานลงบนรถคันที่ 3 \\
\hline$k=1$ & $+-6 \rightarrow 2 \cos t=400$ & (1)- & (1) $\rightarrow$ (2) $\cos t=300$ \\
\hline$k=2$ & (2) $\rightarrow$ (4) $\cos t=300$ & $\cos t=500$ & (2) $\rightarrow$ (4) $\cos t=300$ \\
\hline$k=3$ & (3) $\rightarrow$ (1) $\cos t=400$ & $\cos t=400$ & $\rightarrow 5^{+} \rightarrow 6 \quad \cos t=650$ \\
\hline Total Cost & 1,100 & 1,200 & 1,250 \\
\hline
\end{tabular}

จากตัวอย่างเป็นการแทรกงานขนส่งจากโหนด 5 (เครื่องหมาย + หมายถึง รับสินค้า) ไปยังโหนด 6 (เครื่องหมาย หมายถึง ส่งสินค้า) ลงบนเส้นทางเดิมของรถแต่ละคัน ซึ่งต้นทุนที่ได้จากการแทรกงานเกิดจากการคำนวณต้นทุนขนส่งตาม ระยะทางของเส้นทางใหม่ที่เกิดขึ้น ในที่นี้คือเส้นทางที่มีโหนด 5 และโหนด 6 อยู่บนเส้นทาง รวมกับต้นทุนขนส่งตาม ระยะทางเดิมของรถขนส่งคันอื่น เป็นต้นทุนการขนส่งรวม ซึ่งจากตัวอย่างมี 3 ทางเลือกในการแทรกงานโดยเส้นทางที่จะถูก เลือกนั้นคือ เส้นทางที่ทำให้เกิดต้นทุนการขนส่งรวมของรถทุกคันต่ำสุดตามวัตถุประสงค์ของงานวิจัย ในที่นี้เมื่อเปรียบเทียบ 
ทั้ง 3 ทางเลือกแล้วพบว่า การแทรกงานขนส่งลงบนรถคันที่ 1 นั้นให้ค่าต้นทุนรวมต่ำสุด จึงให้งานขนส่งจากโหนด 5 ไปยัง โหนด 6 ดำเนินการโดยรถคันที่ 1

\section{5. ผลการทดสอบ}

การทดสอบคุณภาพฮิวริสติกของรูปแบบปัญหางานวิจัยการจัดเส้นทางเดินรถแบบเปิดสำหรับการรับและส่งสินค้าด้วย ข้อมูลแบบพลวัตที่ข้อมูลความต้องการขนส่งทยอยรับเข้าและสามารถเปลี่ยนแปลงได้ (Dynamic) โดยเป็นการเปรียบเทียบ ค่าความแตกต่างของต้นทุนการขนส่งที่ได้จากการปรับเส้นทาง เพื่อตอบคำถามของวัตถุประสงค์การทดสอบด้วยกัน 2 ข้อ คือ 1) ฮิวริสติกที่นำเสนอด้วยวิธีการแทรกงาน (Insertion Heuristic) มีประสิทธิภาพในการให้คำตอบที่ดีสำหรับรูปแบบ ปัญหาที่มีการปรับเส้นทาง โดยทำการทดสอบคุณภาพฮิวริสติกจากผลคำตอบที่ได้จากการจัดเส้นทางแบบพลวัต (Dynamic) เปรียบเทียบกับการจัดเส้นทางแบบสถิต (Static) ที่ให้คำตอบของการจัดเส้นทางที่ดีที่สุด เพราะเป็นการนำ ข้อมูลงานขนส่งจริงทั้งหมดจัดเส้นทางเพียงครั้งเดียว ซึ่งถ้าฮิวริวติกที่นำเสนอที่ใช้กับการปรับเส้นทางให้คำตอบที่ดีใกล้เคียง กับการจัดเส้นทางสถิตที่เป็นคำตอบที่ดีที่สุดได้นั้นก็จะแสดงให้เห็นว่า ฮิวริสติกนี้มีประสิทธิภาพสำหรับการจัดเส้นทางของ แบบปัญหาพลวัต (Dynamic) และวัตถุประสงค์การทดสอบที่ 2) ฮิวริสติกที่นำเสนอด้วยวิธีการจัดเส้นทางแบบแทรก (Insertion Heuristic) มีประสิทธิภาพที่สามารถลดต้นทุนขนส่งได้ เมื่อเปรียบเทียบกับวิธีการจัดเส้นทางด้วยวิธีการอื่นที่มีผู้ ศึกษามาก่อนหน้านี้ โดยวิธีการจัดเส้นทางอย่างง่ายที่ผู้วิจัยเลือกมาทำการเปรียบเทียบคือ Nearest Neighbor Heuristic มี หลักการคือ เป็นการจัดเส้นทางโดยพยายามวิ่งไปที่จุดใกล้ที่สุดจากจุดปัจจุบัน ซึ่งจากการศึกษางานวิจัยที่เกี่ยวข้อง [13] Nearest Neighbor เป็นวิธีการหนึ่งของปัญหาการเดินทางของพนักงานขาย (Travelling Salesman Problem: TSP) ที่ สามารถใช้ในการแก้ไขปัญหาการจัดเส้นทางเดินรถได้อย่างง่ายและรวดเร็ว อีกทั้งยังเป็นวิธีดั้งเดิมที่ใช้กันอยู่ทั่วไป

การทดสอบคุณภาพของฮิวริสติกที่นำเสนอนี้เป็นการเปรียบเทียบค่าเปอร์เซ็นต์ความแตกต่างระหว่างต้นทุนการขนส่ง ตามระยะทางที่ได้จากการจัดเส้นทางแบบสถิต (Static) กับต้นทุนการขนส่งที่ได้จากการจัดเส้นทางแบบพลวัต (Dynamic) มีวีธีการคำนวณดังนี้

$$
\% \text { ความแตกต่างต้นทุน }=\frac{\text { ต้นทุนปรับเส้นทาง }(\text { dynamic })-\text { ต้นทุนเส้นทางสถิต }(\text { static })}{\text { ต้นทุนเส้นทางสถิต }(\text { static })} \times 100
$$

โดยที่ต้นทุนเส้นทางสถิต (Static) คือ ต้นทุนที่คำนวณได้จากเส้นทางของงานขนส่งทั้งหมดหลังการปรับปรุงข้อมูลแล้วและ ไม่มีการเปลี่ยนแปลงอีก ส่วนต้นทุนปรับเส้นทาง (Dynamic) คือ ต้นทุนที่คำนวณได้จากเส้นทางใหม่หลังการแทรกงาน ตัวอย่างข้อมูลที่ใช้ในการคำนวณและวิธีการคำนวณต้นทุนจากการจัดเส้นทางทั้ง 2 รูปแบบ แสดงดังรูปที่ 7 


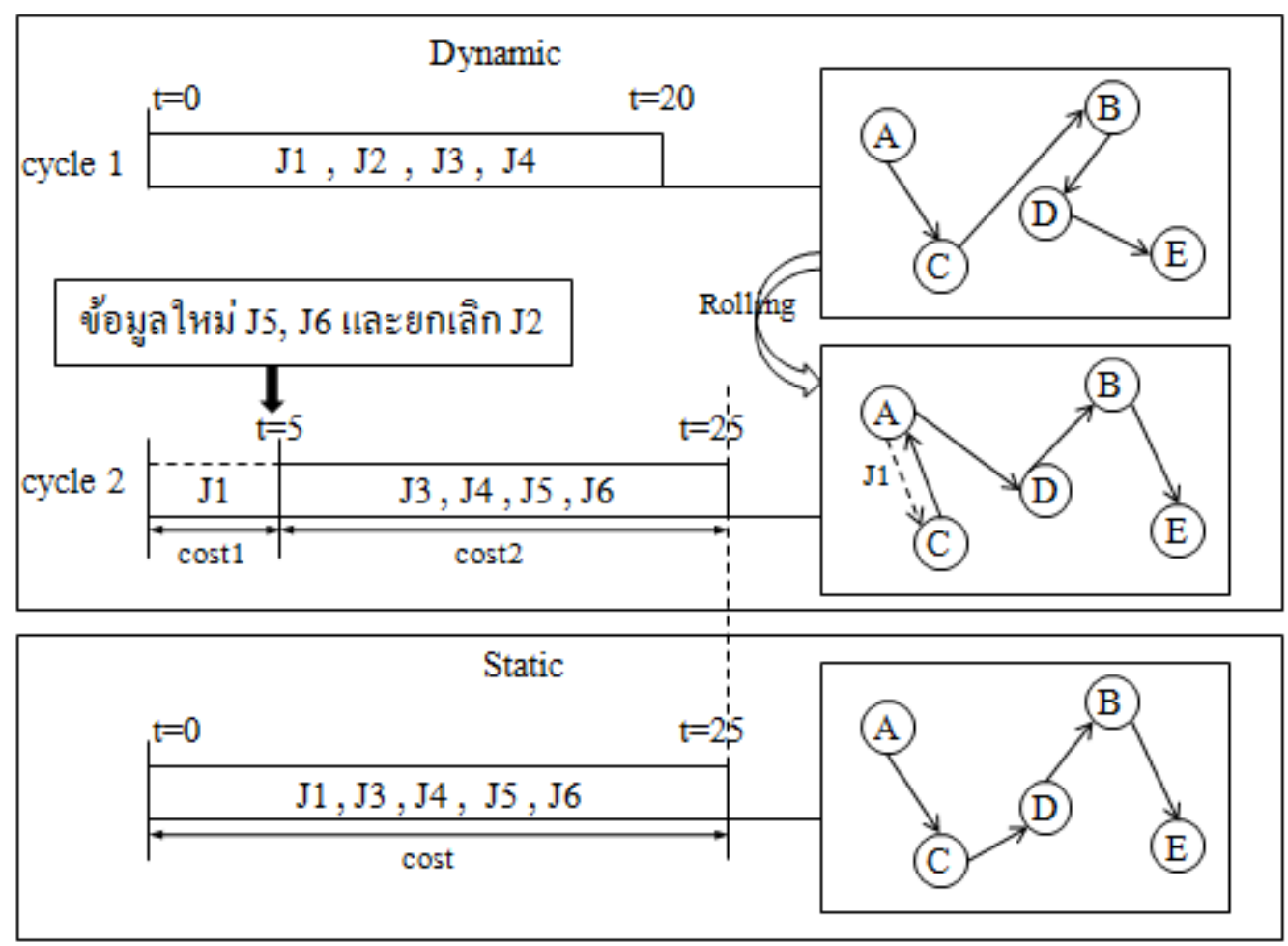

รูปที่ 7

การคำนวณต้นทุนปรับเส้นทางและต้นทุนเส้นทางสุทธิ

จากรูปที่ 7 ในส่วนของการจัดเส้นทางที่มีการเปลี่ยนแปลงของข้อมูลเมื่อเวลาผ่านไป (Dynamic) สามารถอธิบายได้ ดังนี้งานขนส่งที่เป็นข้อมูลครั้งแรก (cycle1) ของการจัดเส้นทาง คือ $\mathrm{J} 1, \mathrm{~J} 2, \mathrm{~J} 3, \mathrm{~J} 4$ เส้นทางที่ได้คือ A-C-B-D-E ใช้เวลาใน การเดินทางขนส่ง $t=0$ ถึง $t=20$ เมื่อเวลาผ่านไป $t=5$ ข้อมูลงานขนส่งมีการเปลี่ยนแปลงโดยงานขนส่งเดิม $J 2$ ยกเลิกและมี งานขนส่งใหม่ $\mathrm{J} 5$ และ $\mathrm{J} 6$ เพิ่มเข้ามา ทำให้เส้นทางขนส่งเดิมหลังจาก $\mathrm{t}=5$ เป็นต้นไปมีการปรับแผนการเดินทาง (rolling) ซึ่ง เส้นทางใหม่ที่ได้จากการจัดครั้งที่สอง (cycle2) คือ C-A-D-B-E และสิ้นสุดการขนส่งที่ $t=25$ ต้นทุนจากการปรับเส้นทางที่ เกิดขึ้น คือ ต้นทุนเส้นทางของงาน $\mathrm{J} 1$ (cost1) และต้นทุนเส้นทางของงาน $\mathrm{J} 3, \mathrm{~J} 4, \mathrm{~J} 5, \mathrm{~J} 6$ (cost2) รวมกัน เมื่อเปรียบเทียบ กับการจัดเส้นทางที่ข้อมูลทั้งหมดไม่มีการเปลี่ยนแปลง (static) เป็นการจัดเส้นทางครั้งเดียวตั้งแต่ $t=0$ ถึง $t=25$ ของงาน ขนส่ง $\mathrm{J} 1, \mathrm{~J} 3, \mathrm{~J} 4, \mathrm{~J} 5, \mathrm{~J} 6$ และต้นทุนขนส่งจากการจัดเส้นทางด้วยข้อมูลสุทธิ (cost) คือ ต้นทุนการขนส่งของเส้นทาง A-CD-B-E

ในการทดสอบคุณภาพผู้วิจัยได้ทำการออกแบบลักษณะข้อมูลความต้องการขนส่งดังนี้

1. สุ่มจำนวนความต้องการขนส่งสินค้า $50-200$ งาน แต่ละงานสุ่มขนาดน้ำหนักและปริมาตรระหว่าง $20 \%-100 \%$ ของความจุรถขนส่ง

2. สุ่มจุดรับและจุดส่งสินค้าของงานขนส่งจากจุดทั้งหมดที่กำหนดขึ้น ซึ่งงานขนส่งจะมีช่วงกว้างของระยะเวลาการ ขนส่งอยู่ระหว่าง $2-3$ วัน

3. สุ่มระดับของจำนวนงานขนส่งที่เปลี่ยนแปลงไปจากจำนวนงานขนส่งทั้งหมด การเปลี่ยนแปลงความต้องการขนส่งที่ มีความเป็นไปได้ ได้แก่ การเพิ่มเข้ามาของข้อมูลใหม่ หรือข้อมูลเดิมมีการเปลี่ยนแปลงเวลารับส่งสินค้า หรือมีการ ยกเลิกข้อมูลเดิม โดยปัจจัยการทดสอบด้านเปอร์เซ็นต์ของจำนวนข้อมูลที่เปลี่ยนแปลงมีความสำคัญต่อการทดสอบ คุณภาพฮิวริสติกในการปรับเส้นทางการขนส่งเพื่อที่จะสามารถตอบได้ว่าฮิวริสติกที่นำเสนอนี้ให้คำตอบที่มี 
ประสิทธิภาพหรือไม่ และการตอบสนองต่อการเปลี่ยนแปลงของจำนวนข้อมูลเป็นอย่างไร ซึ่งการเปลี่ยนแปลงของ จำนวนข้อมูลนั้นเป็นรูปแบบหนึ่งของปัญหาการจัดเส้นทางเดินรถในงานวิจัยนี้

ในการทดสอบผู้วิจัยได้ทำการทดสอบตามปัจจัยที่ออกแบบไว้โดยแต่ละระดับของการเปลี่ยนแปลงข้อมู ลทดสอบซ้ำ ด้วยกัน 4 ปัญหา เพื่อหาค่าเฉลี่ยของแต่ละคำตอบจากแต่ละวิธีการคำนวณการจัดเส้นทาง ซึ่งผลที่ได้ดังตารางที่ 2 แสดง ค่าเฉลี่ยต้นทุนการขนส่งที่ได้จากการจัดเส้นทางเพียงครั้งเดียว (Static) และต้นทุนการขนส่งที่ได้จากการปรับเส้นทางเป็น รอบด้วยวิธีฮิวริสติกแบบการแทรกงานที่นำเสนอ (Insertion Heuristic) และจากวิธีการ Nearest Neighbor Method เพื่อใช้ ในการเปรียบเทียบ

ตารางที่ 2 ค่าเฉลี่ยต้นทุนการขนส่งตามระยะทาง

\begin{tabular}{|c|c|c|c|}
\hline \multirow{2}{*}{$\%$ ข้อมูลเปลี่ยนแปลง } & \multirow{2}{*}{$\begin{array}{l}\text { ต้นทุนเส้นทาง } \\
\text { สถิต (Static) }\end{array}$} & \multicolumn{2}{|c|}{ ต้นทุนปรับเส้นทาง (Dynamic) } \\
\hline & & Insertion & Nearest Neighbor \\
\hline 5 & 26,526 & 26,633 & 28,038 \\
\hline 8 & 40,429 & 40,879 & 43,300 \\
\hline 10 & 42,210 & 42,422 & 46,220 \\
\hline 12 & 35,889 & 36,399 & 38,689 \\
\hline 15 & 40,231 & 41,518 & 43,892 \\
\hline 17 & 46,673 & 47,625 & 50,220 \\
\hline 18 & 42,332 & 44,096 & 46,057 \\
\hline 20 & 52,278 & 53,895 & 57,140 \\
\hline 22 & 53,395 & 55,970 & 59,162 \\
\hline 24 & 49,620 & 50,788 & 53,292 \\
\hline 25 & 58,279 & 60,393 & 64,981 \\
\hline 28 & 53,055 & 54,583 & 59,793 \\
\hline 30 & 55,481 & 58,035 & 61,307 \\
\hline$\%$ ความแตกต่างต้นทุน & & $2.55 \%$ & $9.06 \%$ \\
\hline
\end{tabular}

จากผลการทดสอบกับปัญหาตัวอย่างการจัดเส้นทางจำนวน 52 ปัญหาพบว่า ต้นทุนการขนส่งจะแปรผันตามระดับของ จำนวนงานขนส่งที่เปลี่ยนแปลง เมื่อเปรียบเทียบคำตอบต้นทุนปรับเส้นทางที่ได้จากการจัดเส้นทางเป็นรอบด้วยข้อมูลความ ต้องการขนส่งแบบพลวัต (Dynamic) ด้วยวิธีการจัดเส้นทางของฮิวริสติก Insertion Method ที่นำเสนอให้ค่าใกล้เคียงกับ ต้นทุนเส้นทางสถิต (Static) ที่เป็นคำตอบที่ดีที่สุดจากการจัดเส้นทางของข้อมูลความต้องการขนส่งจริงทั้งหมดเพียงครั้ง เดียว ซึ่งต้นทุนปรับเส้นทางมีค่าห่างจากต้นทุนเส้นทางสถิตเท่ากับ $2.55 \%$ โดยเฉลี่ย และที่ระดับการเปลี่ยนแปลงของ จำนวนงานขนส่งต่ำนั้น ต้นทุนการปรับเส้นทางกับต้นทุนสถิตไม่มีความแตกต่างกันอย่างเห็นได้ชัด สาเหตุที่ทำให้การจัด เส้นทางเดินรถแบบเปิดของการปรับแผนการขนส่งยังคงให้ค่าคำตอบที่ดี เนื่องจากมีการคำนวณปรับแผนเส้นทางทุกครั้งเมื่อ 
มีงานขนส่งใหม่เข้ามาและด้วยวิธีฮิวริสติกที่เป็นการแทรกงานลงบนเส้นทางเดิมที่ให้คำตอบที่มีระยะทางต่ำอยู่แล้วนั้น ทำ ให้เส้นทางใหม่ที่ได้ไม่แตกต่างจากเดิมมากนัก จึงสามารถสรุปได้ว่าฮิวริสติกที่นำเสนอในการจัดเส้นทางเดินรถแบบเปิดของ งานวิจัยมีความน่าเชื่อถือสำหรับการจัดเส้นทางแบบพลวัต (Dynamic) ที่จะต้องทำการปรับเส้นทางเมื่อมีข้อมูลความ ต้องการขนส่งทยอยรับเข้าและสามารถเปลี่ยนแปลงไปตามเวลา

จากผลการทดสอบตารางที่ 2 ชี้ให้เห็นว่าการจัดเส้นทางด้วยวิธี Insertion Heuristic ของงานวิจัยนี้สามารถลดต้นทุน การขนส่งลงได้ โดยต้นทุนปรับเส้นทางจากวิธีของ Insertion Heuristic มีค่าต่ำกว่าจากวิธี Nearest Neighbor เฉลี่ย $6.51 \%$ และเมื่อพิจารณาปัจจัยการทดสอบด้านระดับจำนวนงานขนส่งที่เปลี่ยนแปลงแต่ละครั้ง ถึงแม้ว่าความแตกต่างต้นทุนจาก การปรับเส้นทางจะแปรผันตามระดับของจำนวนการขนส่งที่เปลี่ยนแปลง แต่ จากการสังเกตค่าความแตกต่างของต้นทุน เส้นทางสถิต (Static) กับต้นทุนปรับเส้นทางของวิธีการ Insertion สามารถตอบสนองต่อข้อมูลพลวัต (Dynamic) ได้ดีกว่า โดยให้ค่าคำตอบความแตกต่างต้นทุนเฉลี่ยอยู่ที่ $2.55 \%$ และเมื่อมีการเปลี่ยนแปลงข้อมูลที่เพิ่มขึ้นจะส่งผลให้ต้นทุนการ ขนส่งสูงขึ้นแบบคงที่ ทำให้ผลที่ได้มีช่วงกว้างของคำตอบที่น้อยกว่าเมื่อเทียบกับวิธี Nearest Neighbor ที่มีความแตกต่าง ต้นทุนเฉลี่ยเท่ากับ $9.06 \%$ โดยต้นทุนการขนส่งจะเพิ่มมากยิ่งขึ้นเมื่อข้อมูลมีการเปลี่ยนมาก เพราะวิธีการแทรกงานนั้นเป็น การเพิ่มงานขนส่งลงในเส้นทางเดิมที่ก่อนหน้านี้ได้ทำการจัดเส้นทางให้มีต้นทุนการขนส่งที่ต่ำอยู่แล้ว รวมถึงวิธีการแทรก งานยังมีการคำนวณเปรียบเทียบเส้นทางที่เป็นไปได้ทั้งหมดจำนวนมากกว่าเมื่อเทียบกับวิธีการของ Nearest Neighbor เพื่อ เลือกเส้นทางที่มีต้นทุนการขนส่งต่ำสุดนั่นเอง ดังนั้นจึงสามารถทำให้สรุปได้ว่าการจัดเส้นทางเดินรถแบบเปิดด้วยวิธีการ Insertion Heuristic ที่นำเสนอในงานวิจัยนี้ให้ค่าของคุณภาพคำตอบที่ดีในการลดต้นทุนการขนส่ง รวมถึงยังให้ผลคำตอบที่ รวดเร็วในการปรับเปลี่ยนเส้นทางใหม่อีกด้วย

\section{6. สรุปผลวิจัย}

บทความนี้เป็นการนำเสนอฮิวริสติกของการจัดเส้นทางเดินรถแบบเปิด (Open Vehicle Routing) ที่รถขนส่งไม่จำเป็นต้อง กลับมายังจุดตั้งต้นปล่อยรถ และมีข้อมูลความต้องการขนส่งที่สามารถเปลี่ยนแปลงและเพิ่มเข้ามาใหม่ ซึ่งมีวัตถุประสงค์ ของงานวิจัยคือ การลดต้นทุนการขนส่งรวม จากผลการทดสอบสามาถสรุปได้ 2 ประเด็นคือ (1) วิธีการ Insertion Heuristic ที่ผู้วิจัยเลือกนำมาประยุกต์ใช้ในการแก้ปัญหานี้มีประสิทธิภาพที่สามารถลดต้นทุนการขนส่งโดยให้ค่าคำตอบที่ต่ำกว่าเมื่อ เทียบกับวิธีการจัดเส้นทางเดินรถอย่างง่ายอีกวิธีหนึ่ง และ (2) วิธีการ Insertion Heuristic ที่ผู้วิจัยนำเสนอนี้ยังมี ประสิทธิภาพในการแก้ปัญหาการจัดเส้นทางเดินรถที่ข้อมูลทยอยรับเข้า (Dynamic) โดยสามารถตอบสนองได้ดีกับข้อมูลที่ มีการเปลี่ยนแปลง โดยมีช่วงกว้างของค่าคำตอบที่น้อยกว่าและให้คุณภาพของคำตอบจากการปรับเปลี่ยนเส้นทาง (Dynamic) ที่ใกล้เคียงกับการจัดเส้นทางแบบสถิต (Static) รวมถึงยังใช้เวลาต่ำกว่าในการคำนวณเส้นทางใหม่อีกด้วย อย่างไรก็ตามในการพัฒนาวิธีการทางฮิวริสติกในการจัดเส้นทางเดินรถขนส่งแบบเปิด สามารถทำได้โดยการเพิ่มเงื่อนไขของ การขนส่งที่มีคุณสมบัติพิเศษของสินค้า สถานที่แต่ละแห่งที่มีคุณสมบัติต่างกันออกไป อีกทั้งยังสามารถเพิ่มการพิจารณา ต้นทุนการขนส่งในเรื่องของต้นทุนคงที่และต้นทุนที่เกิดจากการรอคอย รวมถึงพิจารณาเวลาที่ใช้ในการโหลดสินค้าเพิ่ม ขึ้นมาด้วย 


\section{บรรณานุกรม}

[1] อัทธ์ พิศาลวานิช, “การศึกษาโครงสร้างต้นทุนโลจิสติกส์ของไทยและการวิเคราะห์ผลกระทบจากราคาน้ำมัน," วารสารวิชาการมหาวิทยาลัยหอการค้าไทย, ปีที่ 30 , ฉบับที่ $1,2553$.

[2] D. Sariklis and S. Powell, "A heuristic method for the open vehicle routing problem," Journal of the Operation Research Society, vol. 51, pp. 564-573, 2000.

[3] S. A. MirHassani and N. Abolghasemi, "A particle swarm optimization algorithm for open vehicle routing problem," Expert Systems with Applications, vol. 38, pp. 11547-11551, 2011.

[4] E. E. Zachariadis and C. T. Kiranoudis, "An open vehicle routing problem metaheuristic for examining wide solution neighborhoods," Computer \& Operations Research, vol. 37, pp. 712-723, 2010.

[5] F. Li, F. Gloden, and E. Wasil, "The open vehicle routing problem: Algorithms, large-scale test problems, and computational results," Computer \& Operation Research, vol. 34, pp. 2918-2930, 2007.

[6] R. Liu and Z. Jiang, "The close-open mixed vehicle routing problem," European Journal of Operational Research, vol. 220, pp. 349-360, 2012.

[7] X. Li, S. C. H. Leung, and P. Tian, "A multistart adaptive memory-based tabu search algorithm for the heterogeneous fixed fleet open vehicle routing problem," Expert Systems with Applications, vol. 39, pp. 365-374, 2012.

[8] F. Daneshzand, "The Vehicle-Routing Problem," in Logistics Operations and Management, Elsevier Inc., 2011, pp. 127-153.

[9] D. Pisniger and S. Ropke, "A general heuristic for vehicle routing problems," Computer \& Operations , vol. 34, no. 8, pp. 2403-2435, 2007.

[10] G. Berbeglia, J. F. Cordeau, and G. Laporte, "Dynamic pickup and delivery problems," European Journal of Operational Research, vol. 202, pp. 8-15, 2010.

[11] ปารเมศ ชุติมา. เทคนิคการจัดตารางการดำเนินงาน. กรุงเทพมหานคร: สำนักพิมพ์แห่งจุฬาลงกรณ์มหาวิทยาลัย. 2546.

[12] กฤศณภัทร สวาสดิ์, "การกำหนดเส้นทางเดินรถแบบพลวัต," วิทยานิพนธ์ปริญญามหาบัณฑิต, ภาควิชาวิศวกรรม อุตสาหการ คณะวิศวกรรมศาสตร์ จุฬาลงกรณ์มหาวิทยาลัย, 2549.

[13] C. A. J. Hurkens and G. J. Woeginger, "On the nearest neighbor rule for the traveling salesman problem," Operation Research Letters, vol.32, pp. 1-4, 2004. 